\title{
The Effect of HU308/TGF-ß3 Combination on Wound healing, Cell Proliferation and Protein Secretion of MG-63 Osteoblast Monolayers
}

\author{
M. Genedy ${ }^{1,2}$, M. Youseffi ${ }^{1}$, A. Abdeldayem ${ }^{1,2}$, M. Denyer ${ }^{2}$ \\ ${ }^{1}$ School of Engineering Design and Technology-medical engineering, University of Bradford, Bradford, \\ BD71DP, England \\ ${ }^{2}$ School of Life Sciences, University of Bradford, Bradford, BD71DP, England
}

\begin{abstract}
Despite the ongoing political debate regarding the legality of medical marijuana, clinical investigations of the therapeutic use of cannabinoids are now more prevalent than at any time in history. There are mainly two well-known cannabinoid receptors, $C B_{1}$ and $\mathrm{CB}_{2}$. More recently, endocannabinoids (iigands) and their receptors have been identified in the skeleton which appeared to be physiologically regulated by $\mathrm{CB}_{2}$ receptors, furthermore transforming growth factor- $\beta 3$ was found to influence bone healing by regulating extracellular matrix synthesis and angiogenesis [1].This study examined the effect of HU308 treatments in combination with TGF- $\beta 3$ (transforming growth factor beta -3) on wound healing, cell adhesion, cell size and extracellular matrix up regulation of proteins (collagen type I, fibronectin and protein S-100A6) as well as other biological factors such as secretion of matrix metalloproteinase (MMP-2) and nitric oxide (NO). Our results show that combination treatments increased wound closure and decreased cell surface attachment while up regulating $M M P-2$, and nitric oxide.
\end{abstract}

Keywords: cannabinoids, $H U 308, M G-63, M M P-2$, nitric oxide, TGF- $\beta 3$, wound healing

\section{INTRODUCTION}

Bone healing occurs in three distinct but overlapping stages, the early inflammatory stage, the repair stage and the late remodelling stage [1.2.3]. Therefore it is advised that inflammatory or cytotoxic medication should not be used during the 1st stage of injury because that would delay the inflammatory re-sponse during the reactive phase which is responsible for the recruitment of cytokines to the site of injury [3]. One major class of cytokines up regulated in this phase are the transforming growth factor-Betas (TGF- $\beta$ 's), suggesting that TGF- $\beta$ functions in all three phases of wound repair [3]. In vivo studies of skin have shown that TGF- $\beta 3$ promotes wound healing by recruiting inflammatory cells and fibroblasts to the wound site and by facilitating keratinocyte migration [4]. Transforming growth factors are also known to be a potent stimulant of neovascularization and vascular rearrangement. Additionally, observations indicate that TGF- $\beta 3$ activation signals are responsible in stopping terminal differentiation in tissue cells [5]. It has also been indicated that unlike the role of TGF- $\beta$ I and II in inducing scar formation, TGF- $\beta 3$ was shown to reduce scarring and promote better collagen organization in vivo [6]. There is limited research regarding the use of TGF- $\beta$ isomers in bone cell engineering $[7,8]$ and healing compared to other cell types such as keratinocytes $[9,10]$. The rationale for combining CB2 selective agonist with transforming growth factor- beta 3 arises from the idea that the cannabinoids that target $\mathrm{CB} 2$ receptor mainly act down-stream through the MAP Kinase pathway which are a link between membrane-bound receptors and the terminal changes of gene expression. The MAP Kinase pathways are activated by many types of receptors including tyrosine Kinase receptors, cytokine receptors and serpentine Gi-protein-coupled receptors. The MAP Kinase pathway consists of three subfamilies: the extracellular signal-regulated Kinases 1 and 2 (ERK1/2), c-Jun N-terminal Kinase/ stress-activated Kinase, and p38 MAP Kinase (Ofek et al., 2011). Furthermore, they regulate cell proliferation, differentiation and cell survival. The MAP Kinase pathway is also important in regulating the effect of transforming growth factors in cells [11].

Therefore, it is possible that both $\mathrm{CB} 2$ receptor agonists and transforming growth factors may have synergistic effect on cells signalling pathways. Wound healing assays of MG-63 monolayers revealed accelerated wound repair as well as increased cell proliferation mainly regulated through CB2 receptors, and that treatments with HU308 achieved minimum closure timings compared with control groups $(\mathrm{P}<0.05)$.

\subsection{Cell Culture}

\section{MATERIALS AND METHODS}

MG-63 osteoblast-like cells, originally isolated from human osteosarcoma were acquired from ECACC (European Collection of Cell Cultures) and used in this study. The MG63 osteoblasts are a widely used cell line 
[12] because of their ability to retain a differentiated phenotype in culture conditions [13] and because they can be grown for an infinite number of passages. MG63 cells have also been used previously in the study of the integrin-mediated cell-matrix interactions regulated by cytokines and hormones [14,15]. Moreover, the MG63 cell line has been used as a convenient source for purification and identification of known and novel osteoblast transcription factor complexes [16].

In the present study, MG-63 osteoblast cells were cultured in a low glucose (1g/L-D-Glucose) HEPES (25mM) buffered DMEM (Dulbecco's Modified Eagle Media, Sigma Aldrich) culture medium supplemented with L-glutamine $(2.5 \mathrm{mM} \mathrm{U} / \mathrm{mL})$, Penicillin $(100 \mathrm{U} / \mathrm{mL})$, Streptomycin $(0.1 \mathrm{mg} / \mathrm{mL})$, Amphotericin B or a fungizone $(250 \mu \mathrm{g} / \mathrm{ml})$, (Sigma Aldrich-UK) and 10\% FCS v/v (fetal calf serum- PromoCell - UK). Routine sub-cultures were carried out upon reaching $80 \%$ confluency in sterile environment using a laminar flow hood by washing cells three times with Hank's Balanced Salt Solution (HBSS) each time for five minutes, and by adding $1 \mathrm{ml}$ of $0.25 \%$ Trypsin-EDTA (Sigma Aldrich, UK) to detach cells. Once cells became rounded, detachment was stopped by the addition of $2 \mathrm{ml}$ medium containing $10 \%$ FCS. Cells were centrifuged at 1500 $\mathrm{rpm}$, and then diluted using complete medium and counted using a haemocytometer. Cells were plated with an initial cell density of $100,000 \mathrm{cell} / \mathrm{ml}$, culture flaks were always incubated in a $5 \% \mathrm{CO} 2$ air jacket controlled incubator at $37^{\circ} \mathrm{C}$.

Prior to experimentation of different treatments, it was made sure that the same conditions were applied for all experiment groups, in terms of using the same osteoblast cell patch, same culture medium and the same conditions throughout this work. Experimented repeats of different treatments were all carried out with the same stock solutions under the same conditions of cell culture; therefore a common control group was used for all treatments.

\subsection{Preparation of treatments}

HU308 CB2 agonist with a molecular weight of $414.62 \mathrm{~g} / \mathrm{mol}$ (supplied by Tocris bioscience) was diluted according to the suppliers instruction into three different concentrations of $2 \mu \mathrm{M}, 1 \mu \mathrm{M}$ and $500 \mathrm{nM}$. First $1.66 \mathrm{mg}$ was dissolved in $2 \mathrm{ml}$ of $100 \%$ ethanol to make stock solution $(\mathrm{G})$ out of which $5 \mu 1$ was further diluted in $5 \mathrm{ml}$ medium to reach a final concentration of $2 \mu \mathrm{M}$. Out of stock solution $(\mathrm{G}) 1 \mathrm{ml}$ was further added to $1 \mathrm{ml}$ of $100 \%$ ethanol to make stock solution $(\mathrm{H})$, out of which $5 \mu$ was diluted in $5 \mathrm{ml}$ medium to reach a final concentration of $1 \mu \mathrm{M}$. $0.5 \mathrm{ml}$ of stock solution $(\mathrm{G})$ was added to $100 \%$ ethanol to gain stock solution (I) out of which $5 \mu \mathrm{l}$ was diluted in $5 \mathrm{ml}$ medium to reach a final concentration of $500 \mathrm{nM}$. Samples were then stored at $20^{\circ} \mathrm{C}$ freezer according to suppliers instructions.

Human recombined transforming growth factor-beta 3 (Sigma Aldrich, UK) was diluted according to the suppliers recommendation in which $10 \mathrm{mg}$ bovine serum albumin was dissolved in $10 \mathrm{ml}$ of $4 \mathrm{mM}$ hydrochloric acid to obtain $1 \mathrm{mg} / \mathrm{ml} \mathrm{HCl} / \mathrm{BSA}$. This $1 \mathrm{mg} / \mathrm{ml} \mathrm{HCl} / \mathrm{BSA}$ solution was sterilised, using a $0.22 \mu \mathrm{m}$ filter. $10 \mu \mathrm{g} / 40 \mathrm{ml}$ of TGF- $\beta 3$ was dissolved in $0.5 \mathrm{ml}$ of the sterile $1 \mathrm{mg} / \mathrm{ml} \mathrm{HCl} / \mathrm{BSA}$ solution, aliquoted into fifty $10 \mu \mathrm{l}$ vials and stored at $-20^{\circ} \mathrm{C}$, each with a concentration of $200 \mathrm{ng} / \mathrm{mL}$ which was added to $4 \mathrm{~mL}$ media to reach a final concentration of $50 \mathrm{ng} / \mathrm{ml}(8 \mathrm{nM})$.

\subsection{Cell proliferation studies}

The effect of different treatments such as TGF- $\beta 3$ and HU308 combinations on proliferation of MG-63 osteoblastic bone cells with fibroblastic like morphology was assessed. This was done by preparing culture flasks for each treatment group with initial cell densities of 100,000 cells $/ \mathrm{ml}$, after 30 hours in culture. Cells were trypsinized and counted using a haemocytometer; cell densities were compared with the initial plating densities and a proliferation factor was calculated by dividing cell density in cells $/ \mathrm{ml}$ after 30 hours in culture by the plating cell density $(100,000 \mathrm{cell} / \mathrm{ml})$. The experiments were repeated three times for consistency and the mean proliferation factors were calculated.

\subsection{Analysis of cell size (cell length)}

Cell length was measured for every treatment used, i.e. control, TGF- $\beta 3$ and HU308/TGF- $\beta 3$ combined, via acquisition of photomicrographs and measurement using Image $J$ software (NIH). The experiment was repeated three times, mean cell sizes were normalized for all groups and were presented in percentage increase or decrease from the original cell size for control groups $( \pm \mathrm{SE})$.

\subsection{Wound closure assay}

Confluent cell cultures were wounded using a sterilized $1 \mathrm{~mm} \phi$ surgical plastic pipettes to reduce the possibility of contamination, and the timing window for total wound closure of a $300 \mu \mathrm{m}$ width wound in MG-63 bone cell monolayer was found to be $\sim 30$ hours [17]. Culture flasks were treated with either TGF- $\beta 3$ or with combination of $500 \mathrm{nM}$ HU308/8nM TGF- $\beta 3$. Combination treatment was compared against control groups (no treatment). 
The cells were imaged every 5 hours using a phase contrast light microscope and photographed with a digital camera. Pictures were captured and stored as tif images. Using 'Image J' software the distance between the wound edges was measured. Ten vertical lines at semi-random horizontal distances were drawn and the distances between the intersections of the lines with the wound edges were measured. Graphs of percentage wound closure width versus time were plotted for different treatments and controls. Comparisons were made in terms of percentage wound closure and closure rate. All experiments were repeated three times and the data acquired was combined to acquire mean percentage wound width at each time point (Fig 1).

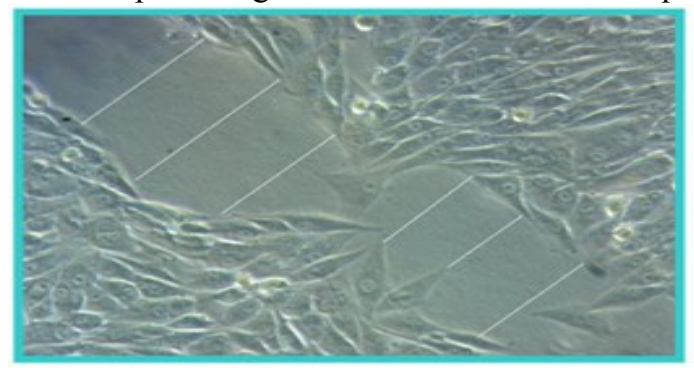

Figure 1. Measurement of wound closure width on cultured MG63 bone cell wounded monolayers using 'Image J' software

\subsection{Cell detachment analysis (trypsinization assay)}

MG-63 Osteoblast cell attachment in both control and treatment groups of TGF- $\beta 3$ and HU308/TGF$\beta 3$ combination were assessed at room temperature using a trypsinization assay. Cells were grown in six-well culture plates in complete media supplemented with TGF- $\beta 3$ and HU308/TGF- $\beta 3$ combination plus controls. After incubation for 30 hours, cells were washed 3 times with Hank's Balanced Salt Solution (HBSS). Cells were then treated with $2 \mathrm{ml}$ of $0.25 \%$ Trypsin-EDTA (Sigma Aldrich, UK) and detachment was monitored using time-lapse photomicroscopy. Images were taken at a sampling rate of 1 frame every 30 seconds over a total period of 4.5 minutes. As cells detach they round up and cell surface decreases. Thus cell detachment rate was measured by monitoring cell surface size reduction using 'Image J' software in the same way, i.e. 20 cells per frame per time point. Experiments were repeated in triplicates for consistency.

\subsection{Immunofluorescence staining for collagen type I, fibronectin and protein S-100A6}

Glycine (used to reduce auto-fluorescence) in HBSS was prepared according to the suppliers instructions $[(0.1 \mathrm{M})=0.375 \mathrm{~g}$ (Glycin $+50 \mathrm{~mL}$ HBSS $)]$ and $4 \%$ formaldehyde was also prepared for cell fixation prior to staining by addition of $4 \mathrm{ml}$ formaldehyde to $32.5 \mathrm{ml}$ HBSS. $1 \% \mathrm{BSA} / \mathrm{HBSS}$ was prepared by addition of $0.5 \mathrm{~g}$ BSA to $50 \mathrm{ml} \mathrm{HBSS}, 500 \mu \mathrm{l}$ Goat serum in $25 \mathrm{ml}$ HBSS was used as blocking agent (Sigma, Aldrich). PBS was prepared by dissolving 1 tablet per $200 \mathrm{ml}$ distilled water and used for washing cells between antibody incubations. Finally, $3 \mu \mathrm{l}$ of dapi was diluted in $30 \mathrm{ml}$ HBSS and this was used for nuclear staining. Primary antibody was prepared in 1\%BSA/HBSS at ratios of 1:500, 1:100 and 1:1000 for collagen type I, fibronectin and S$100 \mathrm{~A} 6$, respectively. Secondary antibody Ab- Alexor fluor $488 \mathrm{nM}$ was diluted by addition of $5 \mu 1$ into $2 \mathrm{ml}$ (1\%BSA/HBSS) to block unspecific binding.

Cells with a total density of 50,000 cells $/ \mathrm{ml}$ were plated on sterilised coverslips in individual petri dishes (3.5 $\mathrm{cm} 2$, CORNIA), this was done by applying $2 \mathrm{ml}$ of cell suspension $(100,000 \mathrm{cells} / \mathrm{ml})$ to their surface. Following a 10 minute attachment period a further $2 \mathrm{ml}$ of complete culture media was added to each of the petri dish containing cover slips.

The petri-dishes were then placed in another larger pe-tri-dish and incubated for 48 hours. After 48 hours dishes were then separated into four treatment cultures, control with no treatment and cells treated with $8 \mathrm{nM}$ TGF- $\beta 3$ and a combination of 500nM HU308/8nM TGF- $\beta 3$. Treatment cells were incubated at $37^{\circ} \mathrm{C}$ in a $5 \% \mathrm{CO} 2$ Atmosphere for 30 hours. The experiments were repeated three times.

Following the final 30 hour incubation, cells were washed three times in HBSS after which cells were fixed in 4\% formaldehyde diluted in HBSS for 5-7 minutes at room temperature. Following fixation, cells were washed twice with HBSS followed by a further wash in the glycine solution. Cells were then permeablized in $0.1 \%$ Triton X-100 solution in HBSS for 3-5 minutes at room temperature and washed three times with HBSS at 15 minutes intervals. To inhibit unspecific staining, cells were treated with Image-iTTM FX signal enhancer. After final incubation with the blocking solution, cells were washed further 3 times in HBSS at 5 minute intervals.

Immunostaining for collagen type 1, fibronectin and protein S-100A6 were achieved by incubating cells in either mouse anti-collagen type I or mouse anti-fibronectin or mouse anti-S-100A6 diluted in HBSS containing $1 \%$ BSA. Negative control cultures (no treatment) were incubated in $1 \%$ BSA/HBSS only. After 1 hour, the primary antibodies were removed and cells were washed 3 times using HBSS at 5 minutes intervals. 
Prior to secondary antibody addition, coverslip edges were dried using plotting paper, afterwards secondary antibody (Alexa Fluor 488 Goat Anti-mouse IgG) at a concentration of $5 \mu \mathrm{g} / \mathrm{ml}$ diluted in $1 \%$ BSA/HBSS was added to all groups for 1 hour at room temperature in the dark. Following this incubation with the secondary antibodies, cells were washed 3 times in HBSS at 5 minutes intervals and finally the slides were placed in foil wrapped petri dishes and maintained at $0-4^{\circ} \mathrm{C}$ in a fridge for 4 days.

Before imaging all cells was incubated in 10\% of dapi (SIGMA) diluted in 1\% BSA/HBSS for 15 minutes in order to identify the nuclei of live cells. Following this incubation in dapi cells were washed 2 times in HBSS at 2 minutes intervals.

Coverslips were removed from petri-dishes and examined using an Eclipse 80i Fluorescence microscope with an objective lens of 60X.

\subsection{Elisa based method for detection of collagen type I, fibronectin and protein S-100A6}

Cells were cultured in $25 \mathrm{~cm}^{2}$ culture flasks under control conditions. On day 3 cells were trypsinized and seeded into a 96 well plate and incubated for a further 30 hours in medium containing treatments of either 8 nMTGF- $\beta 3$ or its combination HU308/TGF- $\beta 3$. After 30 hour incubation, cells were stained for either collagen type I, fibronectin or protein S-100A6. Cells were washed 3 times in PBS and fixed in 4\% formaldehyde for 6 minutes. Cells were washed again in PBS and any endogenous peroxide was quenched using $3 \%$ hydrogen peroxide for 5 minutes. Following another wash, 1\% BSA in PBS was added for 15 minutes to prevent nonspecific binding. Cells were incubated with the primary mouse anti-collagen type I, mouse anti-fibronectin and mouse anti-S-100A6 diluted in 1\% BSA/HBSS at ratios of 1:500, 1:100 and 1:1000, respectively. For negative controls, primary antibody incubation was replaced with a 1\% BSA/HBSS incubation. Following 1 hour of primary anti-body incubation, wells were rinsed and the secondary anti-mouse IgG peroxidise conjugate $(8 \mu \mathrm{g} / \mathrm{ml}$, Sigma) was added for a further 30 minutes at room temperature. Tetramethylbenzidine (TMB) substrate was then applied and absorbance readings were taken at $630 \mathrm{~nm}$ after 10 minutes. This experiment was repeated three times. Absorbance readings for control and test groups were corrected by sub-tracting negative control optical density readings.

\subsection{Nitric oxide quantitative staining}

Seven sets of cells were cultured to reach confluency under normal conditions, after which cells were washed three times for 5 minutes in HBSS and wound were initialized as de-scribed earlier. Each set of cells were fed with media containing either culture media (control), 8nM TGF- $\beta 3$ or $500 \mathrm{nM}$ HU308/8nM TGF- $\beta 3$, combinations. Following treatment, flasks were incubated at $37^{\circ} \mathrm{C}$ in $5 \% \mathrm{CO}_{2}$ atmosphere for 30 hours. Every 5 hours supernatants of a single set were withdrawn from culture flasks and centrifuged at $1700 \mathrm{rpm}$ for 5 minutes. In a coster 96 -well plate, $100 \mu \mathrm{l}$ of each supernatant treatment group was mixed with $100 \mu \mathrm{l}$ Griess' reagent and incubated at room temperature for 10 minutes. After incubation absorbance was measured using absorbance micro-plate reader ELx 800 (Bioteck in-struments, USA) at wavelength of $570 \mathrm{~nm}$. This was repeated every 5 hours up to 30 hours, and experiments were repeated in triplicates.

\subsection{MMP-2 immunoassay staining}

Cells were cultured in $25 \mathrm{~cm}^{2}$ flasks and left in a $5 \% \mathrm{CO} 2$ incubator at $37^{\circ} \mathrm{C}$ to reach confluancy, after which they were divided into the following treatment groups, control (no treatment), 8nM TGF- $\beta 3$ and combination treatment with $500 \mathrm{nM}$ HU308/8nM TGF- $\beta$. Conditioned media was aspirated and centrifuged at $1500 \mathrm{rpm}$ for 5 minutes. An Elisa Kit (Invitrogen,UK) was used and staining steps were in accordance with the manufactures supplied protocol. Conditioned media was added to pre-treated 96-coster well plates with MMP-2 anti-body and were incubated for 2 hours. Media was aspirated and washed 4 times with a washing solution; wells were then incubated in $100 \mu \mathrm{L}$ of biotin conjugate for a period of one hour at room temperature. The wells were again washed 4 times in $1 \%$ BSA/HBSS washing solution. After the final wash, wells were incubated in $100 \mu \mathrm{L}$ of streptavidin-HRP for a period of 30 minutes followed by incubation in stabilized chromogen for 30 minutes in room temperature. Stop solution was added and optical density values were obtained using ELx 800 (Bioteck instruments, USA) at wavelength of $450 \mathrm{~nm}$.

\subsection{Statistical analysis}

Collected data at different time points per treatment were tested for normality using a Kolmogorov Smirnov test. Normally distributed data $(p>0.05)$ were analysed using SPSS via a One way Analysis of Variance (ANOVA) followed by a post Hoc Bonferroni test. Kruskal-Wallis test and serial Mann Whitney tests were used for non-normally distributed results $(\mathrm{p}<0.05)$. Statistical tests were performed such that a $\mathrm{p}$ value of $<0.05$ was considered as indicating a significant difference. There was some variability in initial wound widths therefore, $\%$ wound closure was normalised by computing zero minute of wound gap to be $100 \%$ and wound closure width during 30 hours is represented as correspondent percentages. 


\section{Results and brief discussion}

The cell proliferation assay was carried out on cultures treated with 8nM TGF- $\beta 3$ and 8nM TGF- $\beta 3$ in combination with 500nM HU308 and compared with controls. Interestingly, control groups displayed the lowest proliferation rate $(\mathrm{PF}=1.25)$ after 30 hours in culture. In contrast, cell proliferation was induced in treatments with combination treatments of $8 \mathrm{nM}$ TGF- $\beta 3 / 500 \mathrm{nM}$ HU308 ( $\mathrm{PF}=1.735$ ). Table 1 shows the proliferation factors with different treatments after 30 hours. Statistical analysis showed that proliferation rate with TGF$\beta 3 / \mathrm{HU} 308$ combination treatments was significantly higher $(\mathrm{P}<0.05)$ than control.

Fig 2 shows the images of MG-63 osteoblast bone cells proliferation 30 hours after treatment indicating a more spread morphology. Also, treatment with TGF- $\beta 3$ and their combination HU308/TGF- $\beta 3$ significantly induced increase in cell length by $118 \%$ and $62 \%$ from control groups.

Table1 MG-63 osteoblast proliferation factors with different treatments

\begin{tabular}{|l|l|}
\hline $\begin{array}{l}\text { Osteoblast MG-63 with/without } \\
\text { supplementation }\end{array}$ & $\begin{array}{l}\text { Proliferation factor } \\
\text { after 30 Hours }\end{array}$ \\
\hline Control & 1.25 \\
\hline TGF- $\beta 3$ & 1.85 \\
\hline TGF- $\beta 3$ HUU308 & 1.73 \\
\hline
\end{tabular}

Control

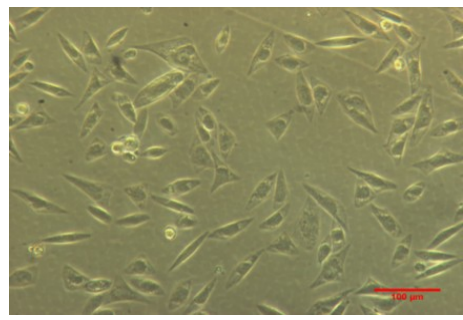

TGF- $\beta 3$

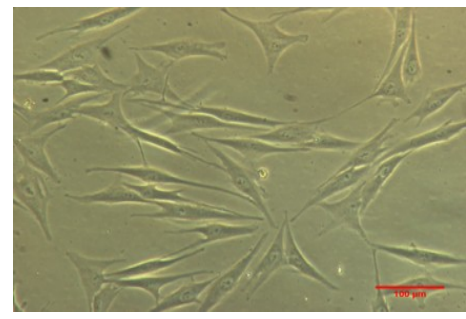

TGF- $\beta 3 / \mathrm{HU} 308$

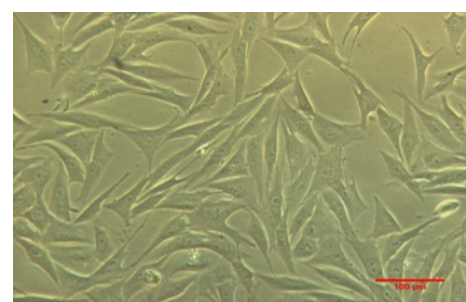

Figure 2. Optical images showing increase in cell length after 30 hours of cell culture (scale bar $=100 \mu \mathrm{M}$ )

Wounded MG-63 osteoblast monolayers were either treated with $50 \mathrm{ng} / \mathrm{ml}$ TGF- $\beta 3$ or combinations of $8 \mathrm{nM}$ TGF- $\beta 3$ with 500nM HU308.

It was found that \% wound width closure varied throughout the 30 hour period in relation to the applied treatment (see Fig 3). After 5 hours, control treated cultures had percentages of wound remained open at $89.96 \% \pm 1.5080$, whereas all other treatments at the same point of time induced significant $\%$ wound closure width compared to control groups $(\mathrm{P}<0.001)$. However, at later time points significant difference between test groups and control groups were evident $(\mathrm{P}<0.01)$. After 10 hours, the $\%$ of wound remained open for cultures treated with a combination of $500 \mathrm{nM}$ HU308/8nM TGF- $\beta 3$ was $47 \% \pm 1.832$ as compared to control at $80.37 \pm 1.968$.

By the 15 hour time point, \% wound remained open was $17.6 \% \pm 1.32$ in the 500 nM HU308/8nMTGF$\beta 3$ combination treated cultures compared to $30.01 \% \pm 2.34$ in the TGF- $\beta 3$ treated cultures $(\mathrm{P}<0.05)$. It was also noted that bridge formation in treatment groups started taking place between hours 15 to 20 , whereas in control groups, bridge formation started to take place after 25 hours, therefore accelerated wound closure was more evident in treatment groups. 


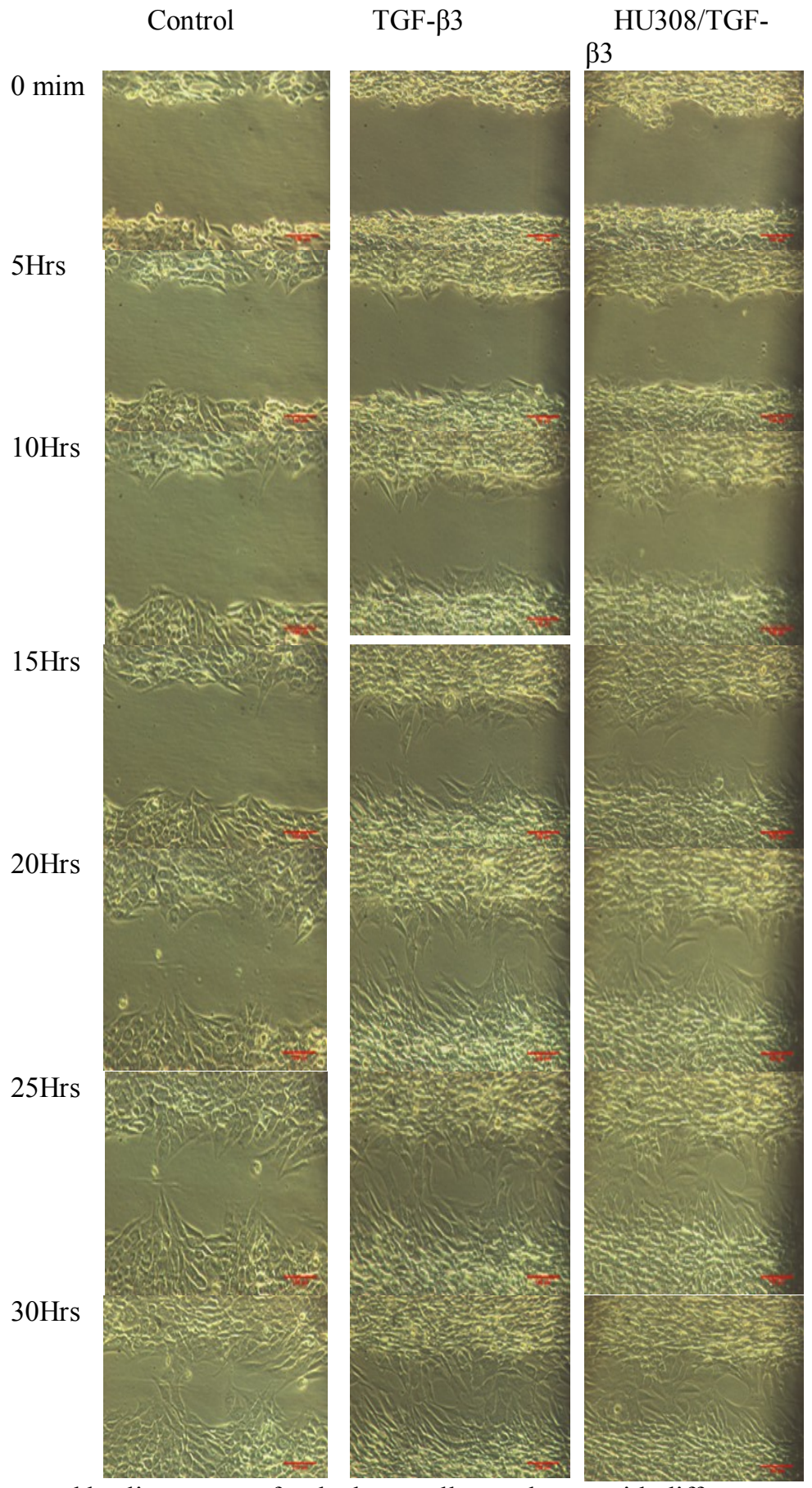

Figure 3. Images of wound healing process for the bone cell monolayers with different treatments compared with control throughout 30 hours (Scale bar $=100 \mu \mathrm{m})$

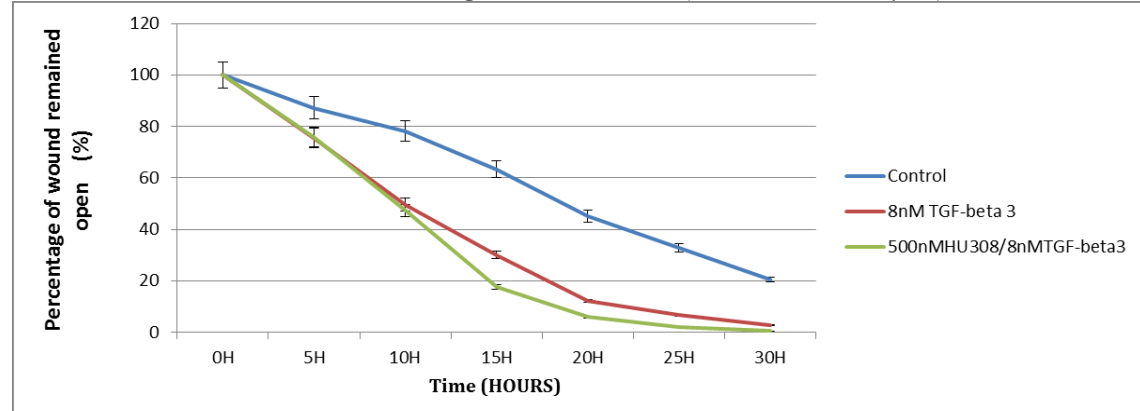

Figure 3. Graph of \% wound closure against time for wounded MG-63 osteoblast monolayers with different treatments. Standard error bars are shown 
The trypsinization assay revealed that treatment with TGF- $\beta 3$ had the shortest time for $\%$ reduction in cell surface area, indicating that TGF- $\beta 3$ reduced cell attachment as compared with the other treatments (see Fig 4).

However, treatments with combinations of TGF- $\beta 3 / \mathrm{HU} 308$ altered the detachment time of MG-63 osteoblast cells as can be seen from Fig 3.7 and Table 3.3. It was found that the percentage decrease in cell surface area after three minutes was $45 \% \pm 1.96$ and $47 \% \pm 1.63$ for TGF- $\beta 3$ and 8 nMTGF- $\beta 3 / 500$ nMHU308 combination groups, respectively, while control decreased by $53.048 \% \pm 2.02$. On the other hand, the percentage decrease in cell surface area after 270 seconds for all treatment groups, i.e. control, 8nMTGF- $\beta 3$ and $500 \mathrm{nMHU} 308 / 8 \mathrm{nMTGF}-\beta 3$ were $42.4 \% \pm 1.8,36.8 \% \pm 2.2$ and $35.4 \% \pm 1.11$, respectively.

Statistical analyses showed that up to 90 seconds there were no significant differences in detachment for all treatments. However, significant differences were observed between treatment groups after 120 seconds and control groups.

In contrast, the study also showed there were no significant differences in detachment time between cells treated with TGF- $\beta 3$ and 8 nMTGF- $\beta 3 / 500$ nMHU308 combination groups $(\mathrm{P}>0.05)$. Overall all TGF- $\beta 3$ treatments promoted cell detachment amongst all tested groups leading to enhanced cell migration.

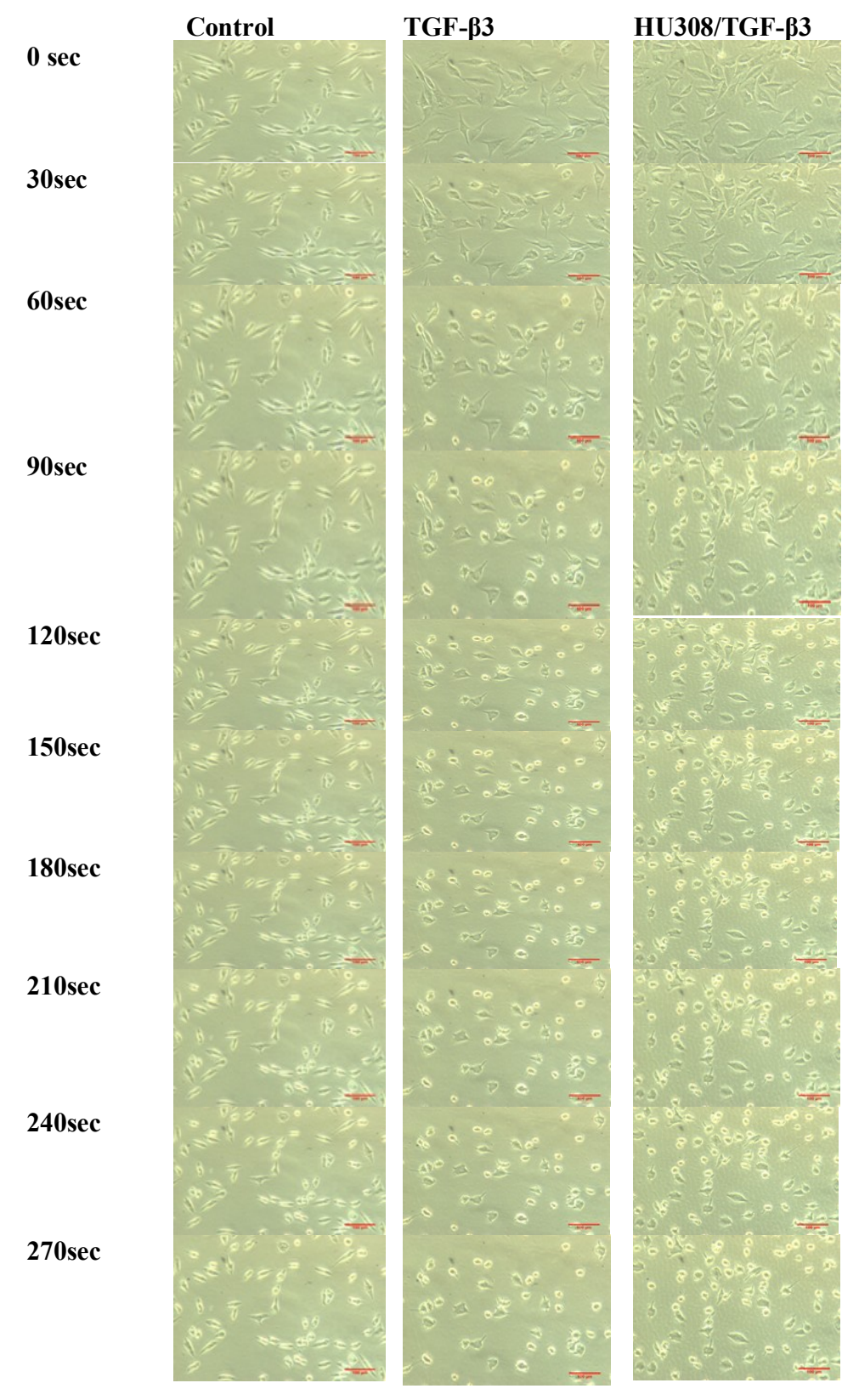

Figure 4. Images showing the effect of trypsinaization on MG-63 osteoblast cells with different treatments (scale bar $=100 \mu \mathrm{m}$ ) 
Immunofluorescence staining was carried out to determine the effect of $8 \mathrm{nMTGF}-\beta 3$ and combination $500 \mathrm{nM}$ HU308/8nM TGF $\beta 3$ on the expression of collagen type I and fibronectin. Immunofluorescence staining of collagen type I after treatment of cells with TGF- $\beta 3$ showed increased collagen expression (Fig 5) where collagen was uniformly distributed around the majority of all cells in a given area compared with control. However, collagen type I expression for groups treated with a combination of 500nM HU308 and 8nM TGF- $\beta 3$ seemed to exhibit a similar but seemingly slightly more enhanced responses as compared with 8nM TGF- $\beta 3$.

Immunofluorescence staining was also carried out for fibronectin expression after treatment with 8nM TGF- $\beta 3$ and 500nM HU308/ 8nM TGF- $\beta 3$ combination, and they were compared with control groups. Interestingly, control groups (no treatment) (see Fig 5) clearly showed fibronectin expression distributed on cell surface and in-between cells, yet the ratio of fibronectin stained cells to dapi stained cells seemed to be quite low indicating a decreased fibronectin expression in control cells. In comparison, fibronectin expression was increased in cells treated with TGF- $\beta 3$ and this can be seen in Fig 5. Also, TGF- $\beta 3$ seemed to induce fibronectin condensations around cell edges and on the culture substrate forming a fibronectin network. This could be as a result of the migrative response that TGF- $\beta 3$ induces in MG-63 osteoblast cells, as more motile have weaker cell attachment with less expression of fibronectin, but they would probably lay down ECM as they migrate. Interestingly, treatments with combinations of $8 \mathrm{nM}$ TGF- $\beta 3 / 500 \mathrm{nM}$ HU308 induced fibronectin expression that seemed to extend into the spaces between the cells indicating fibronectin deposition on the culture substrate. It seemed that fibronectin secretion onto the culture substrate was enhanced by the combination treatment giving rise to the underlying fibronectin layer becoming uniform throughout. Qualitative examination of the immunofluorescence staining for protein S-100A6 indicated that S-100A6 was poorly expressed in control treated cells and cells treated with 500nM HU308 as compared with cells treated TGF- $\beta 3$. This view was supported by a decrease in the proportion of stained cells in control treated cells and the increase in staining intensity in groups treated with $8 \mathrm{nM}$ TGF- $\beta 3$. It was also noted that S-100A6 expression was distributed across entire cells in the 8nM TGF- $\beta 3$ treated cells (Fig 6). However, this was not the case in osteoblast cells treated with a combination of 8nM TGF$\beta 3$ and 500nM HU308 (Fig 6), where the expression of protein S-100A6 was reduced, a fact supported by a decrease in the S-100A6 stained (dapi stained) cell proportions.

\section{Collagen Type I Fibronectin}

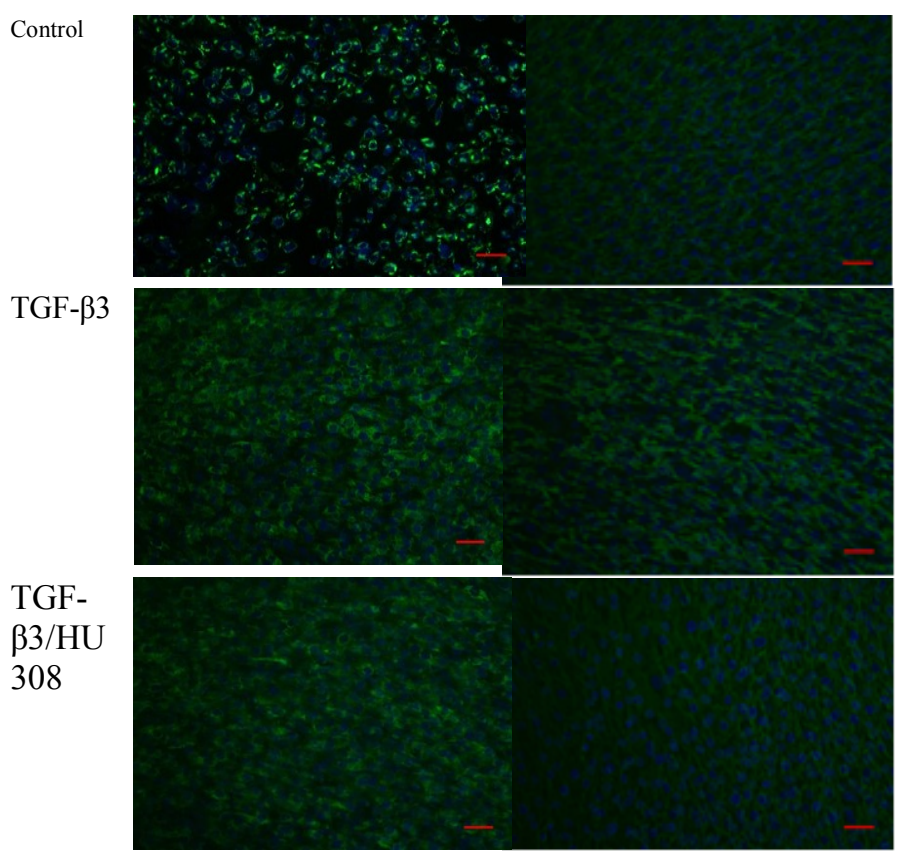

Figure 5. Immunofluorescence staining for collagen type I and fibronectin 


\section{Protein S-100A6}

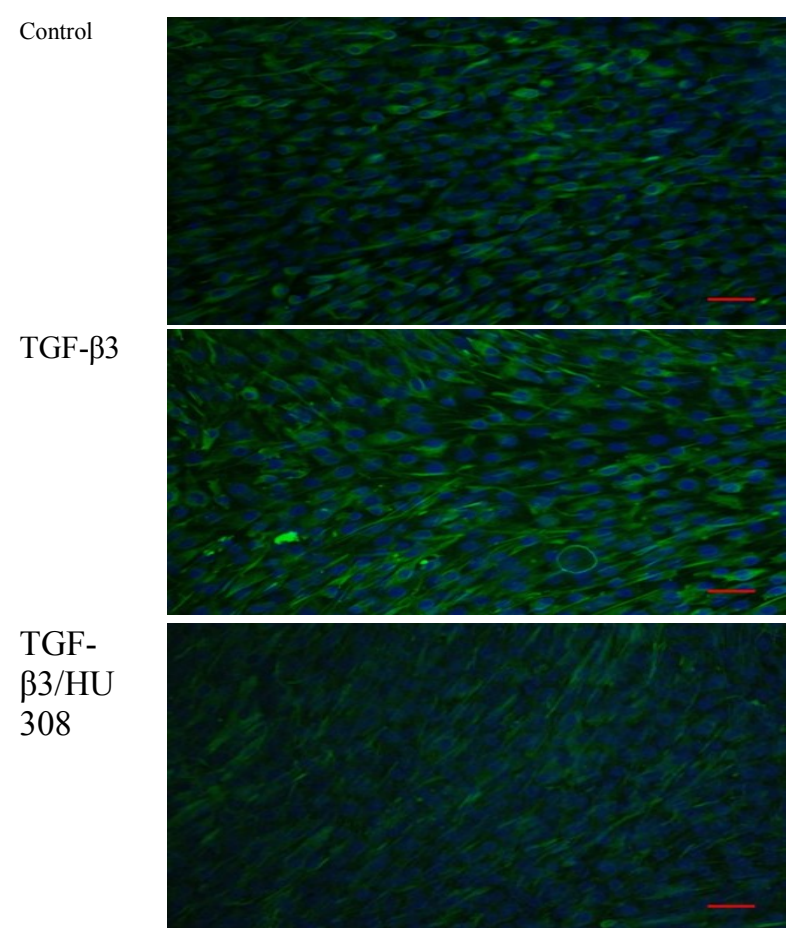

Figure 6. Immunofluorescence staining for protein S-100A6

In order to carry out a more quantitative analysis for significant differences in protein expression induced by a 30 hour incubation with TGF- $\beta 3$ and their combinations (500nM HU308 + 8nM TGF- $\beta 3$ ), an ELISA based immunoperoxidase staining method was used. Readings of optical densities (OD) were compared between control and each treatment used in relation to every protein expression. Absorbance readings for non-treatment (control) cell groups for collagen type I, fibronectin and S-100A6 were OD $=0.69 \pm 0.0014$, OD $=0.65 \pm 0.0022$, $\mathrm{OD}=0.73 \pm 0.0019$, respectively). Primarily observations indicated that protein S-100A6 was relatively higher in MG-63 osteoblast control cultures compared with collagen type I and fibronectin.

However, staining revealed after treatments of TGF- $\beta 3$ or TGF- $\beta 3 / \mathrm{HU} 308$ combinations for ECM expressions, an increased expression of collagen type I and S-100A6 to $\mathrm{OD}=0.97 \pm 0.0021, \mathrm{OD}=0.93 \pm 0.0052$ and $\mathrm{OD}=$ $0.82 \pm 0.0012,0.80 \pm 0.0023$ ) for TGF- 3 and TGF- $\beta 3 / \mathrm{HU} 308$, respectively. In spite of this, fibronectin expression was decreased in both treatments compared with control groups to OD values of $0.63 \pm 0.0021$ and $0.59 \pm 0.0041$ for TGF- $\beta 3$ and TGF- $\beta 3 \backslash \mathrm{HU} 308$, respectively.

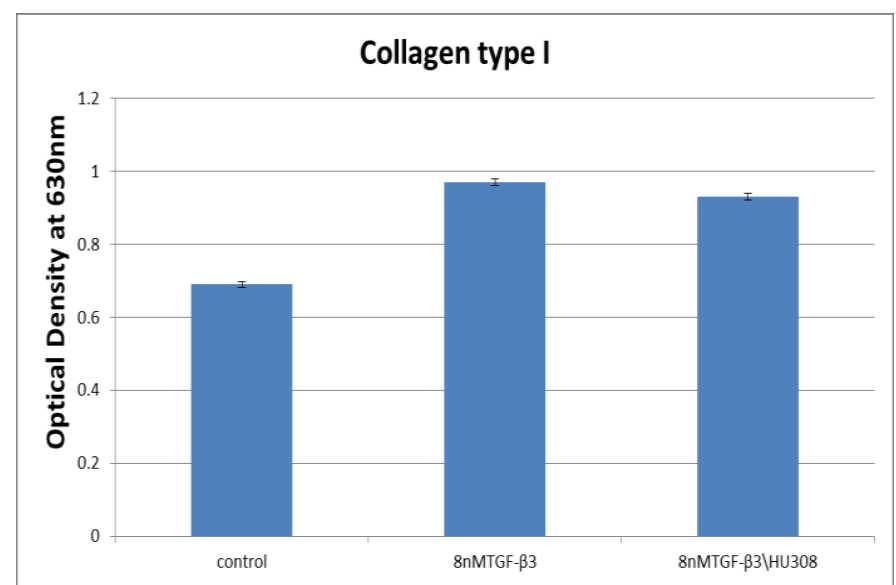

Figure 7. Optical density readings $(630 \mathrm{~nm})$ following immunoperoxidase staining of deposited collagen type I. Standard error bars are shown, $\mathrm{N}=9$. 


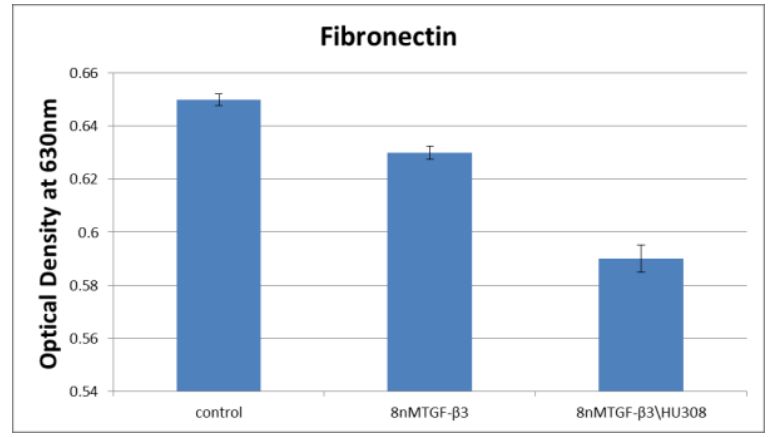

Figure 8. Optical density readings $(630 \mathrm{~nm})$ following immunoperoxidase staining of deposited fibronectin. Standard error bars are shown, $\mathrm{N}=9$.

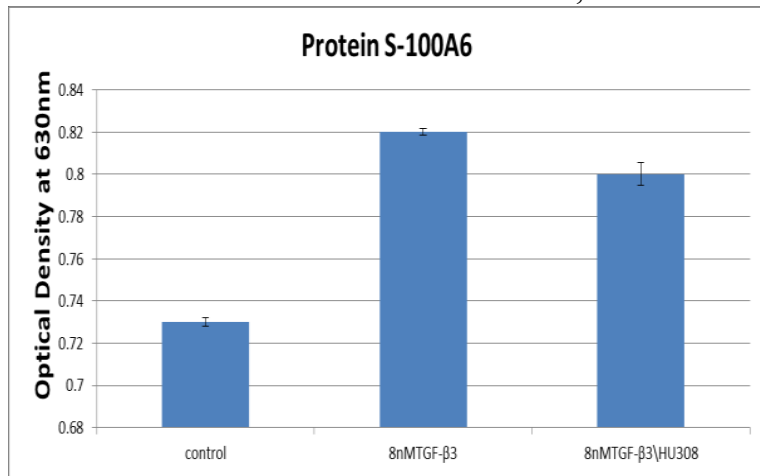

Figure 9. Optical density readings $(630 \mathrm{~nm})$ following immunoperoxidase staining of deposited protein S-100A6. Standard error bars are shown, $\mathrm{N}=9$.

Quantitative staining was carried out for nitric oxide levels throughout 30 hours; readings were taken every 5 hours in order to investigate treatment response by nitric oxide synthesis due to wounded/ damaged cells. The results in Fig 9 indicate that nitric oxide expression in MG-63 osteoblast cell cultures at 0 minute for control, TGF- $\beta 3$ and TGF- $\beta 3 / \mathrm{HU} 308$ combination were with values $\mathrm{OD}=0.75 \pm 0.09, \mathrm{OD}=0.785 \pm 0.014$ and $\mathrm{OD}=$ $0.77 \pm 0.0017$, respectively. After 5 hours, nitric oxide decreased in all treatment groups including control (see Fig9). However, this decrease was not significant in control and 8nM TGF- $\beta 3 / 500 \mathrm{nM}$ HU308 combination which had the least significant optical densities of $0.61 \pm 0.0078$ and $0.62 \pm 0.009$, respectively. After 10 hours, nitric oxide levels were increased and it was notable that nitric oxide elevation reached a peak expression at 15 hours for cultures treated with TGF- $\beta 3$ and TGF- $\beta 3 / \mathrm{HU} 308(\mathrm{OD}=0.90 \pm 0.007, \mathrm{OD}=0.91 \pm .0095$, respectively). In comparison, nitric oxide levels decreased significantly in control treated cells $(\mathrm{P}<0.05)$ after 15 hours to OD $=0.75 \pm 0.014$. Fig 9 also shows that treatments induced significant changes in NO production, especially after 15 to 20 hours indicating a possible role for nitric oxide in the acceleration of MG-63 osteoblast monolayer wound healing.

Immunoassay staining for matrix metalloproteinases-2 (see Fig 10) revealed that for control groups (no treatment) MMP-2 expression was at $\mathrm{OD}=0.75 \pm 0.0025$. A significant increase was observed with treatments of TGF- $\beta 3 /$ HU308 combination $(\mathrm{P}<0.05)$, with value of $\mathrm{OD}=0.87 \pm 0.0016$. On the other hand, TGF- $\beta 3$ treated cells showed increased MMP-2 levels to $\mathrm{OD}=0.77 \pm 0.0033$ compared with control groups at $\mathrm{OD}=0.75 \pm 0.0025$. Interestingly, the percentage increase in MMP-2 levels for treatment groups of $8 \mathrm{nM}$ TGF- $\beta 3 / 500 \mathrm{nMHU} 08$ combination compared to those of control groups, were $16 \%$.

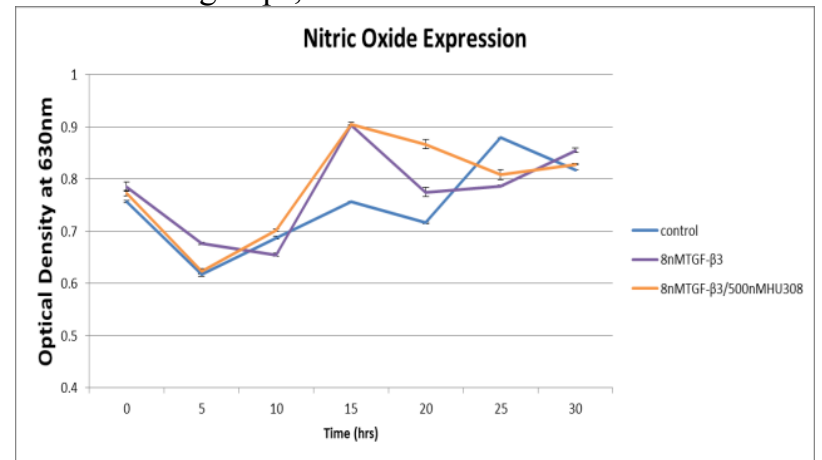

Figure 9. Optical density readings $(570 \mathrm{~nm})$ following immunoassay staining of nitric oxide expression, Standard error bars are shown, $\mathrm{N}=9$. 


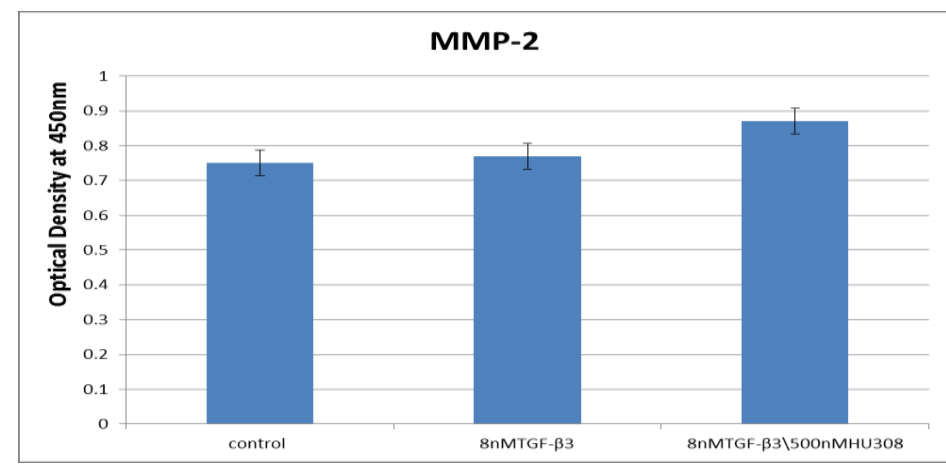

Figure 10. Optical density readings $(450 \mathrm{~nm})$ following immunoassay staining of matrix metalloproteinase-2. Standard error bars are shown, $\mathrm{N}=9$

\section{Discussion}

In this study model wound closure of MG63 bone monolayers after treatment with combinations of $500 \mathrm{nMHU} 308$ and $8 \mathrm{nM}$ TGF- $\beta 3$ combination was investigated and compared to control groups. These experiments were performed using a CB2 selective agonist rather than a CB1 or nonspecific synthetic cannabinoid because it is well known that endocannabinoid activation of pre-synaptic CB1 receptors reduce neurotransmitter release and hence excite toxicity in postsynaptic neurons [18]. There is also evidence that CB1 receptors are involved in direct regulation of vasodilation through vascular $\mathrm{CB} 1$ receptors and indirectly by inhibition of vasoconstrictors[18], and that $\mathrm{CB} 1$ receptors play a part in up regulating pro-inflammatory mediators such as nitric oxide (NO) and TNF- $\alpha$ in the acute phase of injury [18]. There is also evidence that these effects do not directly influence osteoblasts; nevertheless if CB1 agonists or non-specific cannabinoids were used for bone wound repair, they may induce serious side effects and complications such as catalepsy, increased body temperature, analgesia and hyper tension [19]. In comparison, HU308 agonist specifically targets the CB2 receptors which are highly expressed in bone, liver and the immune system. Furthermore, CB1 and $\mathrm{CB} 2$ receptors are not functionally identical, $\mathrm{CB} 1$ is shown to activate potassium ion channels [20] in nerve terminals whilst $\mathrm{CB} 2$ receptor signalling contributes to the maintenance of bone mass by two mechanisms; (i) direct stimulation of stromal cells and osteoblasts and (ii) inhibition of monocytes/osteoclasts both directly and by inhibition of osteoblast stromal cell RANKL expression.

TGF- $\beta 3$ is a member in the TGF-beta family; it was found to be a potent regulator in functions associated with bone formation, i.e. mitogenesis, collagen synthesis, and alkaline phosphatase activity. A role for TGF- $\beta 3$ in bone repair was also suggested after a direct comparison and analysis of receptor competition between TGF- $\beta 1$ and TGF- $\beta 3$. This combined with evidence of picomolar concentrations of high-affinity binding sites for TGF- $\beta 3$ in bone suggest that bone cells are more sensitive to TGF- $\beta 3$ than they are to TGF- $\beta 1$ [21].

In this study it was found that combination treatments with HU308 and TGF- $\beta 3$ induced a comparable proliferation rate with TGF- $\beta 3$ treatments. This response can be explained by the cross and synergetic effect they both have on their signalling pathways further downstream which might have made the pathway less responsive to either or both stimulants. Support for this view comes from evidence that CB2 receptor and Type I and II TGF- $\beta$ receptors both share one of the most important signalling pathways, i.e. P-38 pathway [22.32], and that the response of either treatments could be controlled by receptor affinity to each treatment or by receptor saturation of each treatment. On the other hand, the wound closure assay indicated that treatments with combinations of TGF- $\beta 3$ and HU308 had significantly induced faster wound closure $(\mathrm{P}<0.001)$ compared to control and TGF- $\beta 3$ groups which indicate that other factors may have contributed in the processes of wound healing other than the increase in cell number. Moreover, the wound closure rate of TGF- $\beta 3$ and TGF$\beta 3 /$ HU308 groups were similar compared to control groups. The discrepancy in wound repair rates between cell treated with combination of TGF- $\beta 3 / \mathrm{HU} 308$ and cells treated with TGF- $\beta 3$ compared to control groups is attributed to cell migration. Evidence supporting this was acquired from cell length measurements and trypsinistaion experiments in which it was found that TGF- $\beta 3$ reduced adhesion of MG-63 osteoblast cells. Decreased attachment is documented as being associated with better cell migration. This finding was in complete agreement with a study that showed that Mast cells exhibited enhanced chemotactic responses after treatment with TGF- $\beta 3$ compared to treatment with TGF- $\beta 1$ and 2 [24]. Even though, combination groups showed lower migration rates indicated by trypsinization with no significance in proliferation rate compared to TGF- $\beta 3$ treatment groups, they still achieved accelerated wound closure which may have been as a result of cells having more time to replicate and multiply throughout bridge formation, resulting in the minimizations of the wound gap formation during the 30 hour healing period. It was found that TGF- $\beta 3$ influenced cell morphology and increased cell size by nearly a factor of 2 compared to control cells. In fact, it was shown that 
almost all treatments used in the present study had increased cell length by nearly $60-70 \%$, therefore wound width during wound healing experienced variations in the percentage of the wound remained open especially in TGF- $\beta 3$ treatment groups due to the increased cell size in combination with the effect of cell proliferation, furthermore influencing different responses in terms of wound closure rate. TGF- $\beta$ production by almost all cell type was initially identified in 1978 (Derynck and Miyazono, 2008) in an inactive/latent form [26] suggesting that it plays regulatory roles in most tissues. Although the function of TGF- $\beta$ in various cell types has been investigated, their function in bone repair is as yet not fully understood. There have been studies on the effect of TGF- $\beta$ on bone yet the majority of these studies are not related to bone wound repair. In this study the results indicate that wounded bone monolayers treated with either TGF- $\beta 3$ or combinations with HU308 demonstrated an enhanced ability to repair, in some cases during the first 20 hours following wounding. This may also be related to an increase in secretion of ECM molecules at the wound edge, which functions by capturing cells via the integrin ECM interactions, thus helping migration into the wound site [27]. This view was further supported by significant differences in cell detachment times between each treatment as cells have shown to establish different responses in relation to cell-ECM adhesion strength. This work is the first to examine the effect of synthetic HU308 cannabinoid in combination with TGF- $\beta 3$ on MG-63 wounded bone cell monolayers, therefore providing a potential insight into the mechanisms of wound repair. The importance of investigating the effect of combination treatments, allows better understanding of cell regeneration, as cell biological stimulants are not found selectively in practice or in-vivo. Interestingly, several of other studies have adopted similar approaches in testing drugs in combinations and have shown enhanced findings [28].

HU308 and TGF- $\beta 3$ treatment influenced the production of extracellular matrix proteins MMP-2, S100A6 and NO. In the case of collagen type I expression, 8nM TGF- $\beta 3$ treatment seemed to enhance its expression significantly more than it did for any other treatment. Collagen type I levels were increased by approximately $40 \%$ compared to control treated cells. In comparison combination treatment with $8 \mathrm{nM}$ TGF$\beta 3 / 500 \mathrm{nM} H U 308$ increased expression of collagen type I by approximately $34 \%$. This finding can be explained due to the nature of transforming growth factors which have been shown to increase differentiation for most type of cells [29]. This is also the case in the current investigation with MG-63 osteoblast cells and further confirmed by the increase in protein S-100A6 in TGF- $\beta 3$ treatment cultures. Previous studies have indicated that suppression of collagen synthesis resulted in down regulation of genes associated with osteoblast mineralization [30]. Additionally, it was found that down regulation of cell proliferation due to increasing doses of ascorbic acid induced collagen type I synthesis which in turn increased osteoblast mineralization. This finding was further supported as treatment with 500nMHU308 only significantly induced cell proliferation [31] and induced collagen type I expression by only $10 \%$, whereas in TGF- $\beta 3$ treatment groups, proliferation rate was relatively lower than those obtained for 500nM HU308 groups. However, the $40 \%$ increase in collagen type I expression, is in good agreement and it was also observed in higher concentrations at $2 \mu \mathrm{M}$ HU308 [31] showed lower proliferation rates with increasing levels of collagen type I expression. It was reported that TGF- $\beta 3$ exerts its multiple activities through type I and II cell surface receptors, and that activation of the TGF-beta signal transduction pathways leads to inhibition of cell proliferation and an increase in extracellular matrix production [29] leading to a significant increase in collagen type I expression in most tissues. Therefore, it can be said that involvement of type I collagen extracellular matrix in the developmental expression of osteoblast phenotypic parameters is a physiologically responsive manner in response to different stimulants.

Several studies have also indicated a role for fibronectin in bone repair and remodelling [32]. For example, fibronectin is associated with up-regulation of MMP-2 activation [33] and the expression of fibronectin in cells can alter levels of MMP-2 in culture. Interestingly, the expression of fibronectin in cells treated with TGF- $\beta 3 / \mathrm{HU} 308$ combinations was decreased by $9.2 \%$, compared with control treated cells (no treatment).

The expression of fibronectin has also been associated with cell migration in vitro, and it has been established in a number of studies that the presence or absence of fibronectin deposition around a given cell can determine whether that cell participates in migratory movements during development [34,35]. It was found that the phenotype of a eukaryotic migrating cell appears to be that of lacking cell surface fibronectin in vitro $[34,36]$. This direct relation may be the case for MG63 cells treated with TGF- $\beta 3 / H U 308$. Treatment seemed to decrease levels of fibronectin expression whilst significantly $(\mathrm{P}<0.05)$ in-creasing model wound closure rates. Support for this view comes from the results in this study indicating that not only did combination treatment with TGF- $\beta 3 /$ HU308 decreased fibronectin secretion, but also increased the MMP-2 production.

Percentage increase in fibronectin levels in both the combination 8nM TGF- $33 / 500 \mathrm{nM}$ HU308 and 8 nM TGF- $\beta 3$ groups showed accelerated wound closure, though percentage of fibronectin increase were only $9.2 \%$ and $3 \%$, respectively, compared to control groups, thus indicating to a certain threshold for fibronectin expression that could contribute to maximal migratory response, beyond that threshold reduced migration would occur. This was further supported by the $16 \%$ increase in levels of MMP- 2 expressions following combination treatment with $8 \mathrm{nM}$ TGF- $\beta 3 / 500 \mathrm{nM}$ HU308 compared with controls resulting in enhanced rate of extracellular 
matrix breakage leading to a decrease in adhesion strength and thus enhancing cell migration. This further highlight the crucial role matrix metalloproteinase-2 (MMP-2) plays in bone volume formation [37].

There is evidence that MMP expressions is associated with the mediation of pro-inflammatory cytokines such as IL-1 and TNF- $\alpha$ which are potent inducers of NF-kB (nuclear factor kappa-light-chainenhancer of activated B cells)[38]. NF-kB activation results in growth arrest and cell-cycle arrest at G0/G1 [39] and plays a key role in regulating the immune response to infection. Furthermore, NF-kB activation was found to be responsible for MMP-9 activation but not MMP-2 [38]. Therefore, evidence shows that increases in proinflammatory cytokines in osteoblast cell cultures do not seem to affect levels of MMP-2 in culture [38], and hence it can be concluded that MMP-2 levels found in the current study does not necessarily mirror the inflammation response of osteoblasts as a result of wound initiation. However, they are treatment induced. Interestingly, TGF- $\beta$ in human body is always in the latent form, and in this form TGF- $\beta$ is not recognized by the signalling receptors, hence, the term latency-associated protein (LAP) designates TGF- $\beta$ as propeptide. In order for TGF- $\beta$ to take effect, a family of large secretory glycoproteins known as latent TGF- $\beta$-binding proteins (LTBPs) co-valently bind to LAP via disulfide bonds. LTBPs are not required for maintenance of TGF- $\beta$ latency but may instead facilitate the secretion, storage, or activation of the TGF- $\beta$-LAP complex. However, different types of protease, matrix metalloproteinase- 2 and -9 are implicated in tumour invasion and angiogenesis and also cell surface-bound pro-teases have been shown to activate latent TGF- $\beta$ 's $[40,41]$. This observation indicates that the increased expression of MMP-2 in cultures treated with combinations of TGF$\beta 3 /$ HU308 may play a significant role in activating latent forms of trans-forming growth factor in vivo. TGF- $\beta 3$ and TGF- $\beta 3 / \mathrm{HU} 308$ combination induced slightly S-100A6 expression in the order of $12.3 \%$ and $9.5 \%$, respectively, compared to control treated cells. In general, this increase in S-100A6 expression in osteoblast is generally associated with the differentiation phase [42], however, for MG-63 osteoblast bone cells to achieve maximum wound closure rates bone cells should be in proliferative and migratory states, therefore if cells start to differentiate into mature bone cells with the onset of mineralization, cells would be entrapped inside their own extracellular matrix resulting in the suppression of the wound closure response. Interestingly, this may explain why treatments of MG63 cells with synthetic cannabinoids HU308 at higher concentrations found in a study by [31] decreased wound repair because it may have induced progression towards differentiation rather than proliferation and Migration.

There is a large body of evidence that NO is involved in several inflammatory disorders, and almost all mammalian cells have various immunological parameters that are modulated by nitric oxide, despite their paradoxical effects that have shown to be either pro-inflammatory (immunostimulatory, anti-apoptotic) or antiinflammatory (immunosuppressive, pro-apoptotic) in various situations $[43,44]$. Therefore, it was important to characterize the nitric oxide response on MG-63 wounded osteoblast monolayers and to investigate the effects of different treatments with HU308 and TGF- $\beta 3$.

It was shown throughout 30hours that different treatments influenced NO levels in culture. Treatment with TGF- $\beta 3$ and their combination HU308/TGF- $\beta 3$ induced the highest nitric oxide expression at hours 15-20 with optical density values of $0.903 \pm 0.007,0.91 \pm 0.0095$, respectively, and with a percentage increase $19.3 \%$, $19.6 \%$, respectively, compared to control treated cells after 15 hours. Interestingly, the wound closure experiments showed that treatment with TGF- $\beta 3$ and their combination HU308/TGF- $\beta 3$ increased wound closure, especially after 15-20 hours with a significantly increased proliferation rate. This may be linked to increased nitric oxide production in the osteoblast cells resulting in increased proliferation. This is in agreement with evidence that indicated nitric oxide synthases (NOS) inhibitor (NMMA) induced a dose-dependent inhibitory effect on the proliferation of the osteoblast-like cell lines MG-63 [45]. Therefore nitric oxide expression levels in the present study due to treatments with either synthetic cannabinoid HU308 and TGF- $\beta 3$ might have contributed to increasing MG-63 osteoblast cell proliferation in a dose-dependent manner according to the type of treatment.

Furthermore, it was clearly indicated that the expression of nitric oxide levels in control groups were lower than those in cells treated with TGF- $\beta 3$ and HU308/TGF- $\beta 3$ throughout 25 hours. This could be due to the fact that proliferation levels in control groups was significantly lower than those treatments thus the density of the cells expressing NO in control groups was minimal. Increased levels of nitric oxide reported in groups treated with TGF- $\beta 3$ and its combination TGF- $\beta 3 / \mathrm{HU} 308$ was in contradiction with a recent study that indicated TGF- $\beta 1$ is a negative regulator of nitric oxide production stimulated by IL- $1 \beta$, TNF- $\alpha$ and IFN- $\gamma$ [46]. This contradiction may be due to the difference in the cell lines used in the study or the difference in the transforming growth factor isoform used in the current study.

Overall, the present finding indicates that NO levels after 30 hours was the highest in control groups indicating that treatment with TGF- $\beta 3$ and HU308 played a role in the long term reduction of NO and/or that after 30 hours accelerated wound closure seen in treatment cultures maximized the probability of contact inhibition further leading to a decrease in cell proliferation, as a result reducing levels of nitric oxide expressed by cell population. 


\section{Conclusions}

TGF- $\beta 3$ and its combination with HU308 do not stimulate bone-ECM protein adhesion. Bone cells cultured in medium with TGF- $\beta 3$ supplementation separately displayed a faster rate of cell/surface detachment. This study also supports the evidence in the literature that many cell types take on a migratory phenotype during wound repair and this migratory phenotype can be associated with a change in the degree of cell surface attachment [47]. No clinical research has yet been undertaken on TGF- $\beta 3$ in combination with synthetic cannabinoid, thus this work provided an initial step in evaluating the effects of TGF- $\beta 3$ and TGF- $\beta 3 / \mathrm{HU} 308$ combination in relation to bone wound closure response in-vitro. The results of this work showed that in the case of combined TGF- $\beta 3$ and synthetic CB2 receptor agonist HU308 treated cells, the rate of wound closure was significantly higher $(\mathrm{P}<0.05)$ compared to the untreated controls. This was also observed with 8nMTGF- $\beta 3$ individual treatment cultures which had similar significant (positive) effect $(\mathrm{P}<0.05)$ compared to control groups.

\section{REFERENCES}

[1] Kalfas, I. H. (2001) Principles of bone healing. Neurosurg Focus, 10 (4), E1

[2] Bertone, A. L. (1989) Principles of wound healing. Vet Clin North Am Equine Pract, 5 (3), 449 -63.

[3] Faler, B. J., Macsata, R. A., Plummer, D., Mishra, L. and Sidawy, A. N. (2006) Transforming Growth Factor- $\beta$ and Wound Healing. Perspect Vasc Surg Endovasc Ther. Mar;18(1):55-62

[4] Tyrone, J. W., Marcus, J. R., Bonomo, S. R., Mogford, J. E., Xia, Y. and Mustoe, T. A. (2000) Transforming growth factor beta 3 promotes fascial wound healing in a new animal model. In: Arch Surg. Vol. 135. United States: pp. 1154-9.

[5] Graycar, J. L., Miller, D. A., Arrick, B. A., Lyons, R. M., Moses, H. L. and Derynck, R. (1989) Human transforming growth factorbeta 3: recombinant expression, purification, and biological activities in comparison with transforming growth factors-beta 1 and beta 2. Mol Endocrinol, 3 (12), 1977-86.

[6] Shah, M., Foreman, D. M. and Ferguson, M. W. (1995) Neutralisation of TGF-beta 1 and TGF-beta 2 or exogenous addition of TGF-beta 3 to cutaneous rat wounds reduces scarring. J Cell Sci, 108 ( Pt 3), 985-1002.

[7] Khan, S. N., Bostrom, M. P. and Lane, J. M. (2000) Bone growth factors. Orthop Clin North Am, 31 (3), $375-88$.

[8] Tosounidis, T., Kontakis, G., Nikolaou, V., Papathanassopoulos, A. and Giannoudis, P. V. (2009) Facture Healing and Bone Repair: An Update. Trauma 11: 145-156

[9] Sun, T., Centre for Cell Engineering, U. o. G., Glasgow, United Kingdom, Adra, S., Department of Computer Science, U. o. S., Sheffield, United Kingdom, Smallwood, R., Department of Computer Science, U. o. S., Sheffield, United Kingdom, Holcombe, M., Department of Computer Science, U. o. S., Sheffield, United Kingdom, MacNeil, S. and Department of Engineering Materials, U. o. S., Sheffield, United Kingdom (2009) Exploring Hypotheses of the Actions of TGF- $\beta 1$ in Epidermal Wound Healing Using a 3D Computational Multiscale Model of the Human Epidermis. PLOS ONE, 4 (12).

[10] Shirakata, Y. (2010) Regulation of epidermal keratinocytes by growth factors. J Dermatol Sci, 59 (2), $73-80$.

[11] Ofek, O., Attar-Namdar, M., Kram, V., Dvir-Ginzberg, M., Mechoulam, R., Zimmer, A., Frenkel, B., Shohami, E. and Bab, I. (2011) CB2 cannabinoid receptor targets mitogenic Gi protein-cyclin D1 axis in osteoblasts. J Bone Miner Res, 26 (2), 308-16

[12] Morris, C., Thorpe, J., Ambrosio, L. and Santin, M. (2006) The soybean isoflavone genistein induces differentiation of MG63 human osteosarcoma osteoblasts. In: J Nutr. Vol. 136. United States: pp. 1166-70.

[13] Declercq, H., Van den Vreken, N., De Maeyer, E., Verbeeck, R., Schacht, E., De Ridder, L. and Cornelissen, M. (2004) Isolation, proliferation and differentiation of osteoblastic cells to study cell/biomaterial interactions: comparison of different isolation techniques and source. In: Biomaterials. Vol. 25. England: pp. 757-68.

[14] Broberg, A. and Heino, J. (1996) Integrin alpha2beta1-dependent contraction of floating collagen gels and induction of collagenase are inhibited by tyrosine kinase inhibitors. In: Exp Cell Res. Vol. 228. United States: pp. 29-35.

[15] Riikonen, T., Koivisto, L., Vihinen, P. and Heino, J. (1995) Transforming growth factor-beta regulates collagen gel contraction by increasing alpha 2 beta 1 integrin expression in osteogenic cells. J Biol Chem, 270 (1), 376-82

[16] Newberry, E. P., Boudreaux, J. M. and Towler, D. A. (1997) Stimulus-selective inhibition of rat osteocalcin promoter induction and protein-DNA interactions by the homeodomain repressor Msx2. J Biol Chem, 272 (47), 29607-13.

[17] C.B. Beggs, M.C.T. Denyer, A. Lemmerz, F. Sefat, Member, IAENG, C. Wright, and M. Youseffi, (2010), The Effect of Transforming Growth Factor Beta (TGF- $\beta 3$ ) and Sanicle on Wound Healing, Proceedings of the World Congress on Engineering (WCE 2010), June 30 - July 2, 2010, London, U.K., Volume I, Page: 572-577; ISBN: 978-988-17012-9-9; ISSN: 2078-0958 (Print); ISSN: 2078-0966 (Online).

[18] Ashton, J. C. and Glass, M. (2007) The cannabinoid CB2 receptor as a target for inflammation-dependent. Curr Neuropharmacol, 5 (2), 73-80

[19] Hanuš, L., Breuer, A., Tchilibon, S., Shiloah, S., Goldenberg, D., Horowitz, M., Pertwee, R. G., Ross, R. A., Mechoulam, R. and Fride, E. (1999) HU-308: A specific agonist for CB2, a peripheral cannabinoid receptor.

[20] Caulfield, M. P. and Brown, D. A. (1992) Cannabinoid receptor agonists inhibit Ca current in NG108-15 neuroblastoma cells. Br J Pharmacol, 106 (2), 231-2.

[21] Dijke, P. t., Iwata, K. K., Goddard, C., Pieler, C., Canalis, E., McCarthy, T. L. and Centrella, M. (1990) Recombinant transforming growth factor type beta 3: biological activities and receptor-binding properties in isolated bone cells.

[22] Hocevar, B. A., Brown, T. L. and Howe, P. H. (1999) TGF-beta induces fibronectin synthesis through a c-Jun N-terminal kinasedependent, Smad4-independent pathway. EMBO J, 18 (5), 1345-56.

[23] Herrera, B., Carracedo, A., Diez-Zaera, M., Guzman, M. and Velasco, G. (2005) p38 MAPK is involved in CB2 receptor-induced apoptosis of human leukaemia cells. In: FEBS Lett. Vol. 579. Netherlands: pp. 5084-8.

[24] Olsson, N., Piek, E., ten Dijke, P. and Nilsson, G. (2000) Human mast cell migration in response to members of the transforming growth. J Leukoc Biol, 67 (3), 350-6.

[25] Derynck, R. and Miyazono, K. (2008) TGF- $\beta$ and the TGF- $\beta$ family., Cold Spring Harbor Press.

[26] Schwartz, Z., Bonewald, L. F., Caulfield, K., Brooks, B. and Boyan, B. D. (1993) Direct effects of transforming growth factor-beta on chondrocytes are modulated. Endocrinology, 132 (4), 1544-52.

[27] Nelson, C. M. and Chen, C. S. (2002) Cell-cell signaling by direct contact increases cell proliferation via a PI3K-dependent signal. FEBS Letters, 514 (2), 238-242. 
[28] Ackermann, M., Wolloscheck, T., Wellmann, A., Li, V. W., Li, W. W. and Konerding, M. A. (2011) Priming with a combination of proangiogenic growth factors enhances wound healing. Eur Surg Res, 47 (2), 81-9.

[29] Miettinen, P. J., Ebner, R., Lopez, A. R. and Derynck, R. (1994) TGF-beta induced transdifferentiation of mammary epithelial cells to mesenchymal cells: involvement of type I receptors. J Cell Biol, 127 (6 Pt 2), 2021-36.

[30] Owen, T. A., Aronow, M., Shalhoub, V., Barone, L. M., Wilming, L., Tassinari, M. S., Kennedy, M. B., Pockwinse, S., Lian, J. B. and Stein, G. S. (1990) Progressive development of the rat osteoblast phenotype in vitro: reciprocal relationships in expression of genes associated with osteoblast proliferation and differentiation during formation of the bone extracellular matrix. J Cell Physiol, $143(3), 420-30$.

[31] M. Genedy, M. Youseffi and M.C.T. Denyer. (2012) Effect of CB 2 Selective agonist on wounded bone cell monolayers. 22ND Annual Symposium Of the international cannabinoid Research society Konzerthaus Freiburg Im Breisgau, International Cannabinoid Research Society Research Triangle Park, NC USA P2-2

[32] Yamada, K. M. (2000) Fibronectin peptides in cell migration and wound repair.

[33] Lynch, M. P., Stein, J. L., Stein, G. S. and Lian, J. B. (1995) The influence of type I collagen on the development and maintenance of the osteoblast phenotype in primary and passaged rat calvarial osteoblasts: modification of expression of genes supporting cell growth, adhesion, and extracellular matrix mineralization. In: Exp Cell Res. Vol. 216. United States: pp. 35-45.

[34] Ahmed, Z., Underwood, S. and Brown, R. A. (2000) Low concentrations of fibrinogen increase cell migration speed on. Cell Moti 1 Cytoskeleton, 46 (1), 6-16.

[35] Brunner, M., Millon-Frémillon, A., Chevalier, G., Nakchbandi, I. A., Mosher, D., Block, M. R., Albigès-Rizo, C. and Bouvard, D. (2011) Osteoblast mineralization requires $\beta 1$ integrin/ICAP-1-dependent fibronectin deposition. The Rockefeller University Press J. Cell Biol. Vol. 194 No. 2 307-322

[36] Ruoslahti, E. (1984) Fibronectin in cell adhesion and invasion. Cancer Metastasis Rev, 3 (1), 43-51

[37] Inoue, K., Mikuni-Takagaki, Y., Oikawa, K., Itoh, T., Inada, M., Noguchi, T., Park, J. S., Onodera, T., Krane, S. M., Noda, M. and Itohara, S. (2006) A crucial role for matrix metalloproteinase 2 in osteocytic canalicular formation and bone metabolism. In: J Biol Chem. Vol. 281. United States: pp. 33814-24.

[38] Ben-David, D., Livne, E. and Reznick, A. Z. (2012) The involvement of oxidants and NF-kappaB in cytokine-induced MMP-9 synthesis by bone marrow-derived osteoprogenitor cells. Inflamm Res, 61 (7), 673-88.

[39] Mogi, M., Ozeki, N., Nakamura, H. and Togari, A. (2004) Dual roles for NF-kappaB activation in osteoblastic cells by serum deprivation: osteoblastic apoptosis and cell-cycle arrest. In: Bone. Vol. 35. United States: pp. 507-16.

[40] Yu, Q. and Stamenkovic, I. (2000) Cell surface-localized matrix metalloproteinase-9 proteolytically activates TGF-beta and promotes tumor invasion and angiogenesis. Genes Dev, 14 (2), 163-76

[41] Walsh, L. A., Damjanovski, S., Walsh, L. A. and Damjanovski, S. (2011) IGF-1 increases invasive potential of MCF 7 breast cancer cells and induces activation of latent TGF- $\beta 1$ resulting in epithelial to mesenchymal transition. Cell Communication and Signaling, $99(11), 10$.

[42] Hwang, R., Lee, E. J., Kim, M. H., Li, S. Z., Jin, Y. J., Rhee, Y., Kim, Y. M. and Lim, S. K. (2004) Calcyclin, a Ca2+ ion-binding protein, contributes to the anabolic effects of simvastatin on bone. In: J Biol Chem. Vol. 279. United States: pp. 21239-47

[43] Cirino, G., Distrutti, E. and Wallace, J. L. (2006) Nitric oxide and inflammation. Inflamm Allergy Drug Targets, 5 (2), 115-9

[44] Moncada, S., Palmer, R. M. and Higgs, E. A. (1991) Nitric oxide: physiology, pathophysiology, and pharmacology. Pharmacol Rev, $43(2), 109-42$.

[45] Riancho, J. A., Salas, E., Zarrabeitia, M. T., Olmos, J. M., Amado, J. A., Fernandez-Luna, J. L. and Gonzalez-Macias, J. (1995) Expression and functional role of nitric oxide synthase in osteoblast-like cells. J Bone Miner Res, 10 (3), 439-46

[46] Park, Y. G., Kim, K. W., Song, K. H., Lee, J. M., Hong, J. J., Moon, S. K. and Kim, C. H. (2009) Combinatory responses of proinflamamtory cytokines on nitric oxide-mediated function in mouse calvarial osteoblasts. In: Cell Biol Int. Vol. 33. Netherlands: pp. 92-9.

[47] FOPPIANO, S., TOMSiA, A. P., MARShall, G. W. and BREUNIG, T., ROWE, D.J., (2007) Osteoblast-like cell adhesion on bioactive glasses: surface reactions and resistance to trypsinization. pp. 476-2048. 